\title{
Portuguese Nursing Students' Attitudes towards Lesbians: From Prejudice to Recommendations for Change
}

\author{
Diana Pinto ${ }^{1}$ \\ Centro de Estudos de Comunicação e Sociedade da Universidade do Minho, \\ Braga, Portugal \\ Conceição Nogueira \\ Faculdade de Psicologia e Ciências da Educação da Universidade do Porto, \\ Porto, Portugal
}

\begin{abstract}
This study intends to analyse the attitudes towards lesbians among Portuguese nursing students. For this purpose, a sample of 204 participants, with ages comprised between 18 and 31 years $(M=21)$, completed self-report questionnaires of discrimination and prejudice. The results revealed that nursing students tend to consider the healthcare domain to be the least discriminatory, as opposed to religion, which was considered the most discriminatory domain. The participants' heteronormativity was positively associated with the levels of healthcare discrimination. More negative attitudes were displayed by students living in rural areas and by those without lesbian friends. For this reason, it would be beneficial for students to have access to more information about the challenges posed to the lesbian community via direct contact with lesbians and via the inclusion of such information in their curricula. These practices have the potential to promote a deeper knowledge and more positive attitudes towards lesbians.
\end{abstract}

Keywords: Nursing students, lesbians, healthcare, discrimination, prejudice.

\section{Atitudes de Estudantes Portugueses de Enfermagem relativamente a Lésbicas: Do Preconceito a Recomendações para a Mudança}

\section{Resumo}

Este estudo tem por objetivo analisar as atitudes em relação a lésbicas, demonstradas por estudantes de enfermagem Portugueses. Uma amostra de 204 participantes, com idades entre 18 e 31 anos $(M=21)$, preencheram questionários de autorrelato de discriminação e preconceito. Os resultados revelaram que os estudantes consideram a saúde como a dimensão que menos discrimina, em oposição à religião, que foi considerada a dimensão mais discriminatória. A heteronormatividade dos participantes revelou estar positivamente associada com o nível de discriminação na área da saúde. Atitudes mais negativas foram demonstradas por estudantes que vivem em áreas rurais e por aqueles que não têm amigas lésbicas. Deste modo, seria importante que as alunas tivessem acesso a mais informação sobre as dificuldades enfrentadas pelas lésbicas, através do contato direto com elas e da inclusão de informação a esse respeito nos currículos educativos. Estas práticas têm o potencial de promover um conhecimento mais aprofundado e atitudes mais positivas em relação a lésbicas.

Palavras-chave: Alunos de enfermagem, lésbicas, saúde, discriminação, preconceito.

Mailing address: Universidade do Minho, Centro de Estudos de Comunicação e Sociedade, Campus de Gualtar, Braga, Portugal 4710-057. E-mail: dyanapinto@gmail.com and cnogueira@fpce.up.pt

Note: A partial version of the data from this study were presented in the minutes of the II International Seminar "Contributions of Psychology in Educational Contexts" at the University of Minho in 2012. 


\section{Las Actitudes de los Estudiantes Portugueses de Enfermería relativamente a Lesbianas: Del Perjuicio a Recomendaciones para el Cambio}

\section{Resumen}

Este estudio tiene como objetivo analizar las actitudes hacia lesbianas, demostrados por los estudiantes de enfermería portugueses. Una muestra de 204 participantes, con edades entre 18 y 31 años $(M=21)$ completó cuestionarios auto-administrados de discriminación y prejuicio. Los resultados reblaran que los estudiantes consideran que la salud es la dimensión menos discriminatoria, en oposición a la religión, siendo esta considerada la dimensión más discriminatoria. La heteronormatividad de los participantes se asoció positivamente con el nivel de discriminación en el área de la salud. Actitudes más negativas fueron demostradas por las estudiantes que viven en zonas rurales y por los que no tienen amigas lesbianas. Por eso, sería deseable que las estudiantes tengan acceso a más información acerca de las dificultades que enfrentan las lesbianas, a través del contacto directo con ellas y la inclusión de información sobre el tema en los programas educativos. Estas prácticas tienen el potencial para promover una mejor comprensión y actitudes más positivas hacia las lesbianas.

Palabras clave: Estudiantes de enfermería, lesbianas, salud, discriminación, prejuicio.

The LGBT (lesbians, gays, bisexuals, and transsexuals) population remains a target of discrimination in several axes of their lives, including the healthcare system (Nogueira \& Oliveira, 2010a; Pecheny, 2013). Lesbians are specifically prone to fall victim to this type of discrimination, due to prevailing sexism and to the invisibility of lesbian women in society (e.g., Oliveira, Pena, \& Nogueira, 2011). For instance, health professionals tend to assume that female patients are heterosexual (Daley, 1998). Furthermore, the sexual health of women engaging in sexual encounters with other women has been widely and consistently neglected (Peel \& Thomson, 2009).

Nurses' attitudes, sexual prejudice and/or discrimination seem to influence the healthcare services provided to lesbian (Eliason, Donelan, \& Randall, 1992; Eliason \& Randall, 1991; Parga, Sousa, Costa, \& Ferreira, 2001). Sexual prejudice can be conceptualised as "negative attitudes towards an individual because of her or his sexual orientation" (Herek, 2000, p. 19). An attitude refers to a tendency to evaluate an entity in a more or less favourable or unfavourable way (Eagly \& Chaiken, 2007). Prejudice can result in sexual orientation discrimination, "which refers to the prejudicial and unfair treatment of people based on their sexual orientation" (Ahmed, Andersson, \& Hammarstedt, 2013, p. 568).

Assuming that sexual prejudice does not depend on a single factor, Massey (2009) developed and tested a multidimensional model of sexual prejudice, named Polymorphous Prejudice. The analysis of the different factors unveiled seven dimensions of prejudice:

1. Resistance to heteronormativity, indicating discomfort and resistance towards stereotyped sexual gender roles, for instance, regarding the traditional family roles assigned to women;

2. Traditional heterosexism, as the belief that gays and lesbians are perverted, sinful or immoral, and should have their rights and privileges denied;

3. Positive beliefs about LGBT people, including their positive features and the unique contributions arising out of LGBT's sexual orientation;

4. Aversion toward gay men and

5. Aversion to lesbians, representing the affective reactions that originate discomfort in any eventual contact with lesbians or gays, a need for avoidance, or criticism of their performance in a social context; 
6. Denial of persistent discrimination, as the tendency to believe that situations of homophobic discrimination no longer exist and therefore homosexuals already enjoy equal opportunities compared to heterosexual people; and

7. Value gay progress, referring to pro-diversity values, such as the belief that the LGBT movement plays a valuable role in society.

As important mediators in the health care system, nurses are amongst the professionals that interact more closely with patients (Boch, 2012) and thus enjoy a privileged position to enforce lesbian and bisexual women's rights (Weisz, 2009). Contrarily, nurses continue to display heteronormative attitudes towards these patients (Irwin, 2007; Röndahl, Bruhner, \& Lindhe, 2009). Burch (2008) identified several examples of negative attitudes among healthcare professionals, such as failing to explore same sex relationships as part of the patients' social support networks or to provide health education materials containing relevant LGBT information.

Peterkin and Risdon (2003) noted that the risk factors for the health of the LGBT population are more related to the prejudice present in society than to their identity or to the diversity of sexual orientation. Indeed, several studies have identified homophobia and negative attitudes towards the LGBT population among health care students. Campo-Arias, Herazo and Cogollo (2010) analysed eight studies carried out in the United States, Britain, Germany and Sweden from 1998 to 2008, and identified an incidence of homophobia among nursing students ranging from $7 \%$ to $16 \%$. Some of these studies have found that $8 \%$ to $12 \%$ of a sample of 116 nursing students believed that homosexuality should be punishable by law (Eliason, 1998), and that $7 \%$ of a sample of 180 nursing students openly disapproved homosexuality (Lohrmann et al., 2000). A complementary study (Parga et al., 2001) revealed that $25 \%$ of nursing students believed homosexual relationships to be caused by a psychological disorder, a genetic anomaly, extreme overprotection by the mother, or a combination of these three conditions.
More recently, Boch (2012) conducted a study on the attitudes and knowledge of American nursing students and faculty members about the LGBT community and found homophobic behaviors and attitudes. However, students and faculty professors who were either Democrats or who had LGBT friends displayed less homophobic attitudes. In a different study, Dinkel, Patzel, McGuire, Rols, and Purcell (2007) found low levels of homophobia among nursing students and faculty members, identifying religion and having LGBT acquaintances as the variables with the greatest impact on the variance in levels of homophobia.

Evidence demonstrating that these attitudes and beliefs potentially affect the quality of the health care provided to the LGBT population does seem to exist. Röndahl, Innala and Carlsson (2004) observed that $36 \%$ of nurses and nursing assistants in Sweden admitted that, if given the choice, they would refrain from providing nursing care to homosexual patients, compared to $9 \%$ of students making the same choice. Fortunately, these results suggest that the attitudes towards the LGBT community may be gradually changing. In a Portuguese study (Quintas, 2008), most of the questioned nurses admitted to have little knowledge about the LGBT population or lack of previous academic preparation, but were receptive towards proper training in this area.

Whereas the literature focused on nursing students' attitudes towards the LGBT population is sparse, the literature specifically on lesbians is even scarcer (Randall \& Eliason, 2012). One particular study with female nursing students stands out by reporting five main stereotypes/ themes about lesbians, suggesting that they: seduce heterosexual women; would like to be men; are very ostensive; have a negative influence on children; or contribute to the propagation of sexually transmitted diseases. It also reported other misconceptions about lesbians, such as believing that they are not normal or suffer from a contagious disease. However, students who reported previous contact with lesbians revealed more positive attitudes (Eliason et al., 1992).

Eliason and Randall (1991) also found indications that familiarity and contact with 
lesbians reduce prejudice. Among their sample of nursing students, those who considered themselves more familiar with lesbians had less erroneous ideas about the risk of contracting AIDS and tended to be more favourable towards gay man civil rights. Conversely, students less familiarised with lesbians considered their lifestyle to be unacceptable. In addition, a study conducted in Brazil found that nursing students displayed less prejudice towards gays and bisexuals than towards lesbians and transgender (Parga et al., 2001).

Although this seems to be somewhat consistent across different studies, it should be taken into consideration that attitudes and behaviours are susceptible to change according to the cultural contexts (e.g., Herek \& McLemore, 2013). In Portugal, the literature focusing on this theme is particularly scarce. To the best of our knowledge, this is the first work in this area performed in Portugal. Therefore, this study aimed to understand how Portuguese nursing students perceive lesbian discrimination and identify differences in discrimination and prejudice across some individual and social characteristics, namely, residential area (rural or urban) and familiarity with lesbians.

\section{Method}

\section{Participants}

This study sampled 204 female undergraduate nursing students from the first $(38.24 \%)$, third (34.31\%) and fourth (26.96\%) academic years attending academic institutions in the North of Portugal. Their ages ranged from 18 to $31(M=21)$, most of them being single $(n=197)$ and Portuguese $(n=201)$. Regarding their place of residence, $51.96 \%$ lived in urban areas and $48.04 \%$ in rural areas.

\section{Instruments}

In accordance with the quantitative nature and purposes of this study, we have applied the following instruments:

Socio-Demographic Questionnaire. Includingquestionsaboutage, sexual orientation, nationality, local of residence and political orientation.
Perception of Discrimination. This measure was developed by Oliveira, Pereira, Costa, and Nogueira (2010) to capture students' perceptions of the discrimination against the lesbian community prevailing across different social axes, namely workplace, family, media, religion, friendship, political parties, justice, public administration, healthcare, social security, banks and insurance companies, security and military forces, education and employability. Each axis is measured on a 5-point Likert scale, ranging from 1 (strongly disagree) to 5 (strongly agree). This scale has been previously applied to a Portuguese population in Oliveira and colleagues' study (2010).

Polymorphous Prejudice Multidimensional Questionnaire. This multidimensional measure was originally developed by Massey (2009) to assess attitudes towards gays and lesbians. Costa, Pereira, Oliveira and Nogueira (2010) have previously tested this instrument in the Portuguese context and have demonstrated the reliability of its subscales. Due to the nature of this particular study, we have adapted the Massey Scale and selected only 25 out of 57 items, divided into the following six of the original seven subscales: (a) Resistance to heteronormativity -4 items (e.g., "I feel limited by the sexual behaviors expected of me"); (b) traditional heterosexism - 5 items (e.g., "Female homosexuality is an inferior form of sexuality"); (c) positive beliefs - 4 items (e.g., "I find lesbians more emotionally available than other women"); (d) aversion to lesbians - 4 items (e.g., "It would be upsetting to find that I was alone with a lesbian"); (e) denial of persistent discrimination - 4 items (e.g., "In general, people in our society treat gay people and straight people equally"); (f) value gay progress -4 items (e.g., "The advances made by the gay and lesbian civil rights movement have improved society overall"). We applied a 5-point Likert scale to each item, ranging from 1 (strongly disagree) to 5 (strongly agree). In order to obtain the total of the scale, some items and the subscales referring to positive attitudes (resistance to heteronormativity, positive beliefs and value gay progress) were inverted. In this sense, higher scores in all the subscales and the 
total of the scale reflect higher negative attitudes and prejudice.

Health Discrimination Scale. This scale was designed specifically for this study, based on a previous study (Nogueira \& Oliveira, 2010a). It comprises ten items focusing on the discrimination of lesbians in healthcare. Similar to the previous instruments, we rated its items on a 5-point Likert scale, ranging from 1 (strongly disagree) to 5 (strongly agree; e.g., "Assisted reproduction should also take the lesbian community into consideration"). Higher scores in this scale reflect more discrimination.

\section{Procedures}

We have obtained informed consent and authorisation to carry out the questionnaire with nursing students from two universities located in the North of Portugal. The data has been subsequently collected in a classroom environment where the researcher explained the aims of the study in detail.

\section{Results}

\section{Descriptive Analysis of the Perceived Discrimination Scale}

As presented in Table 1, the field that students consider to be the most prone to discrimination against lesbians is religion $(M=4.59)$, followed by employability $(M=3.71)$ and the workplace $(M=3.37)$. Conversely, these nursing students considered the healthcare sector as the least discriminatory $(M=2.42)$, followed by friendship $(M=2.56)$ and banks or insurance companies $(M=2.84)$.

\section{Table 1}

Descriptive Analysis of the Perceived Discrimination Scale

\begin{tabular}{ccccc}
\hline Domains & N & M & SD & Ranking \\
\hline Religion & 198 & 4.59 & 0.89 & 1 \\
Employability & 203 & 3.71 & 1.12 & 2 \\
Workplace & 201 & 3.37 & 1.18 & 3 \\
Family & 203 & 3.35 & 1.12 & 4 \\
Security and military forces & 202 & 3.15 & 1.27 & 5 \\
Justice & 201 & 3.05 & 1.12 & 6 \\
Public administration & 202 & 3.03 & 1.05 & 7 \\
Media & 204 & 3.01 & 1.17 & 8 \\
Political parties & 204 & 3.01 & 1.00 & 8 \\
Education & 201 & 2.97 & 1.20 & 9 \\
Social security & 203 & 2.85 & 1.08 & 10 \\
Banks and insurance companies & 202 & 2.84 & 1.20 & 11 \\
Friendship & 203 & 2.56 & 1.02 & 12 \\
Healthcare & 202 & 2.42 & 1.11 & 13 \\
\hline
\end{tabular}

\section{Analysis of the Correlations between} the Variables for Polymorphous Prejudice and Lesbian Discrimination in Healthcare

Based on Pearson's correlations between the polymorphous prejudice total (including its subscales) and the lesbian discrimination in healthcare total, we sought to analyse any statistically significant patterns of association. We have found a positive association between traditional heterosexism and aversion to lesbians $(r=.63, p<.01)$ meaning that participants with higher levels of heterosexism also tended to display higher levels of aversion to lesbians. 
Additionally, a significant association was also found between polymorphous prejudice and value of gay progress $(r=.67, p<.01)$, indicating that negative attitudes towards LGBT movement reveal a stronger tendency to display prejudice. A positive association between the scale of discrimination in healthcare and the heteronormativity subscale $(r=.15, p<.05)$ was also observed, indicating that students with higher levels on heteronormativity were more prone to discriminatory attitudes in healthcare.

\section{Differences According to Residential Areas (urban versus rural)}

For the purpose of identifying eventual differences among students living in urban and rural areas, we have carried out a Multivariate Analysis of Variance (MANOVA) of the Polymorphous Prejudice Scale subscales. This generated a significant multivariate result, Wilks' $\lambda=.91, F(6,162)=2.57, p<.05$. Univariate tests revealed differences in the value gay progress, $F(1,167)=8.69, p<.01$, as well as in the denial of persistent discrimination, $F(1,167)=3.95, p<.05$, suggesting that participants from rural areas, when compared to those from urban areas, tend to see the LGBT movement in a more negative way but are less prone to deny the persistent discrimination. These students also marginally differ in traditional heterosexism, demonstrating that those from rural areas display greater levels on this variable, $F(1,167)=3.88, p=.05$ (Table 2$)$.

Table 2

Differences between Subscale Totals by Residential Area

\begin{tabular}{cccccccc}
\hline & \multicolumn{2}{c}{ Rural area $^{\text {a }}$} & \multicolumn{2}{c}{ Urban area $^{\text {b }}$} & & \\
\cline { 2 - 7 } & $M$ & $S D$ & $M$ & $S D$ & $F$ & .879 \\
\hline Resistance to heteronormativity & 17.86 & 2.88 & 17.79 & 3.01 & 0.23 & .051 \\
Traditional heterosexism & 8.30 & 3.44 & 7.36 & 2.68 & 3.88 & .769 \\
Positive beliefs about LGBT & 16.65 & 3.29 & 16.80 & 3.13 & 0.09 & .496 \\
Aversion to lesbian & 6.39 & 3.03 & 6.11 & 2.41 & 0.47 & .048 \\
Denial of persistent discrimination & 8.38 & 2.18 & 9.12 & 2.62 & 3.95 & .054 \\
Value gay progress & 14.23 & 3.04 & 12.86 & 3.04 & 8.67 & .004 \\
\hline
\end{tabular}

${ }^{\mathrm{a}} n=84,{ }^{\mathrm{b}} n=85$.

Regarding the Discrimination Scale totals, we have found significant differences, $t(186)=$ $2.15, p<.05$, revealing that students from rural areas $(M=34.13, S D=3.83)$ tend to be more discriminatory than those from urban areas $(M=$ 32.94, $S D=2.15$ ).

\section{Differences based on Having Lesbian Friends/Acquaintances}

Despite the fact that only 60 participants (29.4\%) reported to have lesbian friends, we decided to analyse the differences in polymorphous prejudice based on this criterion. No significant multivariate results were observed. However, univariate tests were significant in particular subscales - resistance to heteronormativity, $F(1,163)=5.48, p<.05$, positive beliefs about LGBT individuals, $F(1,163)=4.86, p<.05$, and value gay progress, $F(1,163)=6.28, p<.05$, indicating that participants with lesbian friends had lower scores in these variables (Table 3). Because the scores of these variables are inverted, these results suggested that participants with lesbian friends showed more positive beliefs about LGBT, value more the gay progress and show more resistance to heteronormativity.

When considering polymorphous prejudice and discrimination totals, we found significant differences in the polymorphous prejudice total, $t(163)=-2.80, p<.01$, showing that participants with lesbian friends or acquaintances tend to dis- 
Table 3

Differences between Subscale Totals based on Whether or Not Having Lesbian Friends

\begin{tabular}{|c|c|c|c|c|c|c|}
\hline & \multicolumn{2}{|c|}{ Lesbian friends ${ }^{a}$} & \multicolumn{2}{|c|}{ No lesbian friends ${ }^{\mathrm{b}}$} & \multirow[b]{2}{*}{$F$} & \multirow[b]{2}{*}{$p$} \\
\hline & $M$ & $S D$ & $M$ & $S D$ & & \\
\hline Resistance to heteronormativity & 17.02 & 3.49 & 18.15 & 2.60 & 5.48 & .020 \\
\hline Traditional heterosexism & 7.67 & 3.05 & 7.87 & 3.17 & 0.16 & .691 \\
\hline Positive beliefs about LGBT & 15.93 & 3.39 & 17.09 & 3.08 & 4.86 & .029 \\
\hline Aversion to lesbian & 6.39 & 2.50 & 6.17 & 2.87 & 0.23 & .634 \\
\hline Denial of persistent discrimination & 8.70 & 2.01 & 8.73 & 2.62 & 0.00 & .949 \\
\hline Value gay progress & 12.65 & 3.00 & 13.93 & 3.12 & 6.28 & .013 \\
\hline
\end{tabular}

${ }^{\mathrm{a}} n=54,{ }^{\mathrm{b}} n=111$.

play lower levels of prejudice $(M=68.36, S D$ $=8.64)$, in comparison to those without lesbian friends or acquaintances $(M=71.95, S D=7.25)$.

\section{Discussion}

This study first sought to explore the level of discrimination towards the lesbian community perceived by nursing students throughout different social contexts. The health context was reported as the least discriminatory, followed by friendship. These results might derive from the students' lack of knowledge about discrimination in the health sector and/or the perception that subtle and apparently inoffensive attitudes are not highly offensive and discriminatory. In other words, the results suggest some gaps in the nursing students' knowledge about discrimination in healthcare contexts, its forms of expression and its consequences. Alternative explanations may lie in the social desirability or the students' overestimation of their future work environment.

Furthermore, information about lesbians and prejudice remains insufficient, especially in the nursing sector (Randall \& Eliason, 2012). The participants of this study may also perceive other contexts as simply more discriminatory, what might constitute a concerning factor given the levels of homophobia found in healthcare contexts (e.g., Campo-Arias et al., 2010). The context perceived as the most discriminatory was religion, followed by access to employment and the workplace. Thus, these students' perception is consistent with the literature about the influence of religious beliefs (and/or practice) on student homophobic attitudes towards the LGBT population (Eliason, 1998; Röndahl, 2009; Yen et al., 2007).

The results also suggest that nursing students currently living in rural areas tend to judge the LGBT movement more negatively. They also presented a higher level of traditional sexism, but a lower level of denial of persistent discrimination. Additionally, students inhabiting rural areas demonstrated higher levels of discrimination in the health domain. Indeed, existing differences between rural and urban areas have already been reported in the literature. Individuals from rural areas tend to show more traditional values whereas those who live in urban areas are more open to sexual diversity (Nogueira \& Oliveira, 2010b). Nevertheless, students from urban areas were more skeptical about the existence of homosexual discrimination. This may be attributed to the belief on the progress of society - especially in urban areas - insofar that gays and lesbians have the same opportunities of progress, whereas in rural areas the perception of discrimination is presumably more obvious.

Participants with lesbian friends/acquaintances tended to have more positive attitudes. Students that did not mention having lesbian friends or acquaintances had higher levels of prejudice. More specifically, these students showed lower resistance to heteronormativity, 
less positive beliefs about lesbians, and lower agreement with pro-diversity ideals and the potentialities of the LGBT movement. Across the literature, studies have suggested that an increase in students' knowledge and positive attitudes towards the LGBT population decreases students' discomfort in interacting with members of the LGBT population (e.g., Boch, 2012; Yen et al., 2007).

Specifically concerning the interaction with lesbians, the scarce existing literature points out that the familiarity of nursing students with lesbians is one of the best predictors of acceptance and socialisation (Eliason et al., 1992; Eliason \& Randall, 1991). The development of knowledge and positive attitudes towards the lesbian population is thus of utmost importance for an area as crucial as health, where marginalisation poses real and serious risks to the physical and psychological integrity of this particular patient group (Randall \& Eliason, 2012).

Consistent with literature, this study also found significant associations between low resistance to heteronormativity and discrimination in healthcare. In fact, according to previous studies, heteronormativity has been described as being particularly related to the discrimination against the LGBT population by healthcare professionals (e.g., Röndahl, 2009; Röndahl et al., 2009).

However, these results must be interpreted with caution because other external factors may influence such perceptions. For example, our sample was entirely female. Although some authors find that women tend to demonstrate more positive attitudes toward gay people than men (Herek, 2002), other studies failed to report gender differences regarding attitudes toward female homosexuality (Arnold, Voracek, Musalek, \& Springer-Kremser, 2004) or even that women feel more uncomfortable than men in the presence of a lesbian (Jones, Pynor, Sullivan, \& Weerakoon, 2002).

To deepen and complete this study, future studies should include not only nursing professionals and students, but also professionals from other healthcare areas (e.g., Medicine or Psychology). In order to overcome some limitations of this study, future studies should also include male participants, as well as participants from different regions of Portugal. The data collection and treatment processes may also benefit from different methodologies, in particular online surveys and/or interviews, allowing for a more qualitative approach. Future studies should also take into account contextual and cultural differences in prejudice and discrimination and follow appropriate procedures in order to develop more reliable measures for these issues (Borsa, Damásio, \& Bandeira, 2012). Additionally, the use of implicit measures would be potentially enriching in future studies, given the sensitive and complex nature of the themes approached in this study (Cunningham, Preacher, \& Banaji, 2001).

According to McNair (2003), more healthcare education about the lesbian community is urgently required in order to prevent the health services from continuing to be conditioned by the lack of knowledge, inadequate communication, and discriminatory attitudes. It is also important to emphasise that information related to the lesbian community should develop into an area of study on its own right, due to both the particularities and the health risk factors faced by this group (McNair, 2003).

Our results provide evidence of prejudice against lesbians among nursing students and the lack of awareness of the discrimination faced by lesbians in healthcare. More information about this community should be provided during nursing training. The inclusion of information about lesbians in nursing manuals and curricular programs seems to be very important to avoid marginalisation and invisibility of this community (Randall \& Eliason, 2012). Therefore, nursing schools should provide general training and education about LGBT issues and more specifically about lesbians, in order to prevent prejudice against this group of patients, but also as a way of tackling specific health care needs of this group.

Furthermore, healthcare services should disseminate information about lesbian health and equal access to healthcare, especially in the rural areas. Community health campaigns focusing on LGBT health should be specifically designed and promoted in the rural areas, emphasising the di- 
versity of this group and acknowledging the specific needs of lesbians. We would stress the extreme relevance of continuing this line of study in order to be able to provide quality healthcare to sexual minorities, in particular lesbians, who are otherwise invisible due to the conditions of both their female gender and sexual orientation.

\section{References}

Ahmed, A., Andersson, L., \& Hammarstedt, M. (2013). Are gay men and lesbians discriminated against in the hiring process? Southern Economic Journal, 79, 565-585. doi:10.4284/00384038-2011.317

Arnold, O., Voracek, M., Musalek, M., \& SpringerKremser, M. (2004). Austrian medical students' attitudes towards male and female homosexuality: A comparative survey. Wien Klin Wochenschr, 116, 730-736. doi:10.1007/ s00508-004-0261-3

Boch, S. J. (2012). Knowledge, attitudes, behaviors of nursing faculty and students' about lesbian, gay, bisexual and transgender people (Unpublished master thesis). College of Nursing, Ohio State University, $\mathrm{OH}$.

Borsa, J. C., Damásio, B. F., \& Bandeira, D. R. (2012). Adaptação e validação de instrumentos psicológicos entre culturas: Algumas considerações. Paidéia (Ribeirão Preto), 22, 423-432. doi:10.1590/1982-43272253201314

Burch, A. (2008). Health care providers' knowledge, attitudes, and self-efficacy for working with patients with spinal cord injury who have diverse sexual orientations. Physical Therapy, 88, 191198. doi:10.2522/ptj.20060188

Campo-Arias, A., Herazo, E., \& Cogollo, Z. (2010). Homophobia among nursing students. Revista da Escola de Enfermagem USP, 44, 826-830. doi:10.1590/S0080-62342010000300041

Costa, C. G., Pereira, M., Oliveira, J. M., \& Nogueira (2010). Imagens sociais das pessoas LGBT. In C. Nogueira \& J. M. de Oliveira (Eds.), Estudo sobre a discriminação em função da orientação sexual e da identidade de género (pp. 93-147). Lisboa: Comissão para a Cidadania e a Igualdade de Género.

Cunningham, W. A., Preacher, K. J., \& Banaji, M. R. (2001). Implicit attitude measures: Consistency, stability, and convergent validity. Psychologi- cal Science, 12, 163-170. doi:10.1111/14679280.00328

Daley, A. (1998). Lesbian invisibility in health care services: Heterosexual hegemony and strategies for change. Canadian Social Work Review, 15, 57-71.

Dinkel, S., Patzel, B., McGuire, M. J., Rols, E., \& Purcell, K. (2007). Measures of homophobia among nursing students and faculty: A Midwestern perpective. International Journal of Nursing Education, 4, 1-12. doi:10.2202/1548923X.1491

Eagly, A. H., \& Chaiken, S. (2007). The advantages of an inclusive definition of attitude. Social Cognition, 25, 582-602. doi:10.1521/ soco.2007.25.5.582

Eliason, M. J. (1998). Correlates of prejudice in nursing students. Journal of Nursing Education, $37,27-29$.

Eliason, M. J., Donelan, C., \& Randall, C. (1992). Lesbian stereotypes. Health Care for Women International, 13, 37-41. doi:10.1080/07399339 209515986

Eliason, M. J., \& Randall, C. E. (1991). Lesbian phobia in nursing students. Western Journal of Nursing Research, 13, 363-374. doi: 10.1177/019394599101300306

Herek, G. M. (2000). The psychology of sexual prejudice. Current Directions in Psychological Science, 9, 19-22. doi:10.1111/1467-8721.00051

Herek, G. M. (2002). Gender gaps in public opinion about lesbians and gay men. Public Opinion Quarterly, 66, 40-66. doi:10.1086/338409

Herek, G. M., \& McLemore, K. A. (2013). Sexual prejudice. Annual Review of Psychology, 64, 309-333. doi:10.1146/annurevpsych-113011-143826

Irwin, L. (2007). Homophobia and heterosexism: Implications for nursing and nursing practice. Australian Journal of Advanced Nursing, 25, 70-76.

Jones, M. K., Pynor, R. A., Sullivan, G., \& Weerakoon, P. (2002). A study of attitudes toward sexuality issues among health care students in Australia. Jounal of Lesbian Studies, 6, 73-86. doi:10.1300/J155v06n03_07

Lohrmann, C., Välimäki, M., Suominen, T., Muinonen, U., Dassen, T., \& Peate, I. (2000). German nursing students' knowledge of and attitudes to HIV and AIDS: Two decades af- 
ter the first AIDS cases. Journal of Advanced Nursing, 31, 696-703. doi:10.1046/j.13652648.2000.01326.x

Massey, S. (2009). Polymorphous prejudice: Liberating the measurement of heterosexuals' attitudes toward lesbians and gay men. Journal of Homosexuality, 56, 147-172. doi: 10.1080/00918360802623131

McNair, R. (2003). Outing lesbian health in medical education. Women \& Health, 37, 89-103. doi:10.1300/J013v37n04_07

Nogueira, C., \& Oliveira, J. M. (2010a). Um olhar da Psicologia feminista crítica sobre os direitos humanos das pessoas LGBT. In C. Nogueira \& J. M. de Oliveira (Eds.), Estudo sobre a discriminação em função da orientação sexual e da identidade de género (pp. 9-17). Lisboa: Comissão para a Cidadania e a Igualdade de Género.

Nogueira, C., \& Oliveira, J. M. (2010b). Desafiar o futuro. In C. Nogueira \& J. M. de Oliveira (Eds.), Estudo sobre a discriminação em função da orientação sexual e da identidade de género (pp. 267-275). Lisboa: Comissão para a Cidadania e a Igualdade de Género.

Oliveira, J., Pena, C., \& Nogueira, C. (2011). Lesbian Feminism or lesbian feminists? - Voicing Portuguese lesbian claims. Feminism \& Psychology, $21,228-232$.

Oliveira, J. M., Pereira, M., Costa, C. G., \& Nogueira, C. (2010). Pessoas LGBT - Identidades e discriminação. In C. Nogueira \& J. M. de Oliveira (Eds.), Estudo sobre a discriminação em função da orientação sexual e da identidade de género (pp. 149-210). Lisboa: Comissão para a Cidadania e a Igualdade de Género.

Parga, E. J. de S., Sousa, J. H. M. de, Costa, M. C., \& Ferreira, S. L. (2001). Estereótipos e preconceitos de gênero entre estudantes de enfermagem da UFBA. Revista Baiana de Enfermagem, 14, 111-118.

Pecheny, M. (2013). Desigualdades estruturais, saúde de jovens LGBT e lacunas de conhecimento: Que sabemos e que perguntamos? Temas em Psicologia, 21, 961-972. doi:10.9788/TP2013.3EE10ESP

Peel, E., \& Thomsom, M. (2009). Editorial introduction: Lesbian, Gay, Bisexual, Trans and Queer health psychology: Historical development and future possibilities. Feminism \& Psychology, 19, 427-436. doi:10.1177/0959353509342691
Peterkin, A., \& Risdon, C. (2003). Caring for lesbian and gay people: A clinical guide. Toronto, Canada: University Press.

Quintas, P. M. P. (2008). Heteronormatividade no contexto dos cuidados de saúde - Atitudes dos profissionais de Enfermagem em razão da orientação sexual do utente (Unpublished master thesis, University of Porto, Portugal).

Randall, C. E., \& Eliason, M. (2012). Out lesbians in nursing: What would Florence say? Jounal of Lesbian Studies, 16, 65-75. doi:10.1080/108941 60.2011 .557644

Röndahl, G. (2009). Students' inadequate knowledge about lesbian, gay, bisexual and transgender persons. International Journal of Nursing Education Scholarship, 6, 1-15. doi:10.2202/1548923X.1718

Röndahl, G., Bruhner, E., \& Lindhe, J. (2009). Heteronormative communication with lesbian families in antenatal care, childbirth and postnatal care. Journal of Advanced Nursing, 65, 23372344. doi:10.1111/j.1365-2648.2009.05092.x

Röndahl, G., Innala, S., \& Carlsson, M. (2004). Nursing staff and nursing students' emotions towards homosexual patients and their wish to refrain from nursing, if the option existed. Scandinavian Journal of Caring Sciences, 18, 19-26. doi:10.1111/j.1471-6712.2004.00263.x

Weisz, V. K. (2009). Social justice considerations for lesbian and bisexual women's health care. Journal of Obstetric, Gynecologic \& Neonatal Nursing, 38, 81-87. doi:10.1111/j.15526909.2008.00306.x

Yen, C. F., Pan, S. M., Hou, S. Y., Liu, H. C., Wu, S. J., Yang, W. C., \& Yang, H. H. (2007). Attitudes toward gay men and lesbians and related factors among nurses in Southern Taiwan. Public Health, 121, 73-79. doi:10.1016/j.puhe.2006.08.013
Recebido: 10/02/2015

$1^{a}$ revisão: $22 / 05 / 2015$

$2^{a}$ revisão: $1 \% 07 / 2015$

Aceite final: $1 \% 07 / 2015$ 